\title{
PENGARUH MEKANISME CORPORATE GOVERNANCE TERHADAP KINERJA KEUANGAN PERUSAHAAN KELUARGA DI INDONESIA
}

\author{
Adhitya Rechandy Christian Santoso \\ Universitas Ahmad Dahlan \\ adhitya.santoso@mgm.uad.ac.id
}

\begin{abstract}
This study discusses the application of corporate governance to the performance of family companies in Indonesia. The relationship of corporate governance in this study was proxied with an independent board of commissioners, the size of the board of directors, and the size of the audit board. The measurement of the financial performance of this study uses Return On Equity (ROE) with a sample of research companies listed on the Indonesia Stock Exchange in the 2014-2018 period. The sampling method in this study uses purposive sampling and data analysis using multiple linear regression with the help of SPSS 21. The results of data analysis, the proportion of independent commissioners and the size of the board of directors had a significant positive effect on the variable size of the audit board not having a significant effect.
\end{abstract}

Keywords: Mechanism of Corporate Governance; Financial Performance; Family Companies.

\section{PENDAHULUAN}

Kelompok bisnis keluarga di Indonesia memang lazim dijalankan di Indonesia berawal dari perusahaan yang dikelola oleh entrepreneur secara murni yang kemudian berkembang dengan mekanisme dan strategi yang dijalankan oleh pemilik perusahaan untuk berkembang dan menjadi perusahaan yang sesuai dengan prediksi (Lukviarman, 2016). Perkembangan perusahaan keluarga memiliki ciri tetap mempertahankan konsentrasi kepemilikan keluarga walaupun perusahaan yang dikelola sudah menjadi perusahaan terbuka melalui penjualan surat berharga di pasar modal. Sejalan dengan (Claessens,1999) yang menyatakan bahwa perusahaan di Asia memiliki historis serta sosiologis merupakan perusahaan dengan kontrol keluarga. Hal ini diperkuat oleh hasil riset Pricewaterhouse Coopers (2014) yang menyebutkan bahwa $95 \%$ bisnis di Indonesia adalah perusahaan yang dimiliki atau dikelola oleh keluarga sehingga diartikan mayoritas perusahaan di Indonesia merupakan bisnis yang dijalankan dan dikelola oleh keluarga. Dalam teori keagenan, manajemen keluarga memiliki manfaat dalam mencapai tujuan yang menentukan keputusan dan berdampak pada kinerja perusahaan (Anderson et.al, 2003).

Kerangka Kerja pada corporate governance (CG) berfungsi untuk memberikan kewajaran kepada para pemegang saham terhadap terjadiya kecurangan, insider trading dan self dialing yang dilakukan oleh stakeholder perusahaan atau pihak yang memiliki informasi perusahaan. Penerapan good corporate governance (GCG) perlu 
dilakukan karena adanya asumsi bahwa bisnis keluarga pengelolaan dilakukan oleh keluarga sehingga perlu pengawasan guna terciptanya transparasi bahwa perusahaan telah melaksanakan tata kelola perusahaan yang sehat. Penerapan CG pada perusahaan keluarga memiliki perbedaan diantara para peneliti. Asumsi pertama adalah yang menyatakan bahwa pengelolaan perusahaan oleh keluarga cenderung berpengaruh negative karena pemilik perusahaan cenderung melakukan usaha untuk meningkatkan kesejahteraan keluarga tersebut, hal ini diperkuat oleh penelitian yang dilakukan oleh penelitian yang dilakukan oleh Mirales, et al (2006) yang menyatakan bahwa manajemen keluarga berdampak negatif terhadap kinerja keuangan perusahaan. Block et al (2011) juga mengemukakan bahwa keluarga akan menjalan kegiatan menggunakan kepentingan keluarga tersebut. selain hal tersebut, adanya direksi independen dalam perusahaan keluarga juga tidak memberikan dampak terhadap kinerja perusahaan (Leung et.al, 2014). Namun hal ini berbeda dengan penelitian yang dilakukan oleh Santoso (2017) yang menemukan bahwa kepemilikan keluarga memberikan dampak positif bagi kinerja keuangan perusahaan keluarga di Indonesia, selain itu, Allouche et. Al (2008) perusahaan keluarga di Jepang juga mendapat dampak kinerja yang lebih baik dengan adanya kepemilikan keluarga dan dalam system perusahaan Cucuelli et al (2009 menemukan bahwa kinerja perusahaan di Italia, perusahaan dengan kepemilikan keluarga tidak terdapat indikasi superioritas yang dilakukan oleh pemilik perusahaan dalam mengelola perusahaan. Jaggi (2009) juga menemukan bahwa perusahaan di Hongkong juga memiliki kinerja yang baik, Anderson dan reeb (2003) menyampaikan hal yang sama pada perusahaan di Italia dengan mengambil sampel pada perusahaan S\&P 500 bahwa perusahaan dengan ikatan keluarha memiliki pemahaman yang lebih baik pada perusahaanya sehingga mereka dapat menjalankan perusahaan dengan lebih baik. Bahkan lebih lagi pada perusahaan di Jepang, Saito (2008) menemukan perusahan yang dikelola oleh keluarga cenderung lebih unggul daripada perusauhaan non-keluarga. Di Lebanon juga sama bahwa kepemilikan keluarga memberikan dampak positif pada penelitian yang dilakukan oleh Charbel (2013) dan di Taiwan, perusahaan dalam ikatan keluarga memiliki kaitan yang positif dalam kinerja perusahaan (Chen, 2013).

Kinerja keuangan pada penelitian ini menggunakan proksi Return on Equity (ROE) yaitu rasio keuangan yang menggambarkan seberapa besar perusahaan mampu mengelola modal ekuitas yang dimiliki perusahaan. Variabel mekanisme corporate governance penelitian ini diproksikan pada Proporsi Dewan Komisaris Independen, Ukuran Dewan Direksi dan Ukuran Komite Audit. Dewan Komisaris Independen adalah pihak yang tidak terafiliasi secara langsung dalam perusahaan dan berfungsi untuk mengawasi perusahaan. Dewan Direksi memiliki peranan besar dalam pengelolaan semua sumber daya yang ada dalam suatu perusahaan. Komite audit adalah pihak yang bertugas untuk mengawasi proses pelaporan keuangan yang ada pada perusahaan untuk menjaga terjadinya tindak kecurangan dan akan memberikan dampak baik pada pelaporan keuangan pada perusahaan sehingga mampu memberikan gambaran secara jelas kondisi perusahaan. Pada penelitian ini mengambil proksi Komisaris Independen, Proporsi Dewan Direksi dan Komite audit karena proksi tersebut dapat mencerminkan bagaimana mekanisme GCG dilakukan pada perusahaan keluarga dan penelitian ini bertujuan untuk membuktikan secara empiric bagaimana peran Mekanisme GCG pada perusahaan keluarga di Indonesia mengingat masih banyak perbedaan pandangan mengenai kinerja perusahaan keluarga. 


\section{REVIEW LITERATUR DAN HIPOTESIS}

\section{Landasan Teori}

\section{Teori Agensi}

Perspektif teori agensi merupakan dasar yang digunakan guna memahami isu corporate governance. Jensen and Mecking (1976). menyebutkan bahwa manajer pada suatu perusahaan sebagai "agent" dan pemegang saham sebagai seorang "principal". Konsep teori agensi menyatakan bahwa para principal adalah pihak yang memberikan kewenangan kepada agent dalam hal ini principal adalah pemilik modal dan agent adalah manajer. Manajer perusahaan adalah pihak yang mengambil keputusan pada perusahan sehingga manajer menjadi pihak yang lebih mengetahui bagaimana keadaan perusahaan. Namun dalam hal ini manajer wajib memberikan informasi kepada principal yang terkadang informasi yang disampaikan tidak sesuai dengan kondisi perusahaan sehingga dapat ketidaksesuaian ini menimbulkan permasalahan yang sering disebut dengan masalah agensi.

Darmawati (2005), menyatakan bahwa terdapat tiga asumsi yang melandasi toeri keagenan.

a. Asumsi berdasar pada sifat manusia, asumsi ini menjelaskan bahwa manusia memiliki sifat untuk mementingkan diri sendiri, manusia memiliki keterbatasan akan berfikir rasional dan cenderung tidak menyukai resiko.

b. Asumsi berdasar pada organisasi yang menekankan adanya asimetri informasi antara pemegang saham dan manajer.

c. Asumsi yang didasarkan pada informasi yang menganggap bahwa informasi merupakan sebuah komoditas yang bisa diperjual belikan.
Mekanisme corporate goverance dapat berfungsi menjadi alat dan diharapkan prinsip-prinsip dalam CG dapat mengurangi masalah keagenan pada perusahaan dan meningkat kinerja pada perusahaan.

\section{Corporate Governance}

Corporate governance adalah peraturan yang mengatur hubungan antara pemegang saham dan pengelola perusahaan. Forum for Corporate Governance in Indonesia (FCGI) (2004) mendefinisikan Corporate Governance sebagai aturan-aturan yang mengatur hubungan hak dan kewajiban pihakpihak yang memiliki kepentingan terhadap perusahaan seperti hubungan antara para pemegang saham, pengelola perusahaan, pemerintah dan penyedia dana pihak ketiga dalam hal ini seperti kreditur. Nuryaman (2008) mendefiniskan corporate governance sebagai kunci dalam meningkatkan efisiensi ekonomis yang meliputi serangkaian hubungan antara manajemen perusahaan, komisaris, pemegang saham dan stakeholder lainnya. Herawaty (2008) menyatakan bahwa, corporate governance merupakan konsep dari teori keagenan yang memberikan keyakinan kepada investor akan menerima return atas dana yang telah diinvestasikan pada perusahaan. Ujiyanto (2007) juga menyatakan bahwa corporate governance adalah struktur yang dapat memfasilitasi penentuan sasaran-sasaran perusahaan dan untuk menentukan bagaimana teknik monitoring kerja. Penerapan corporate governance yang baik akan meminimalisir terjadinya tindakan fraud yang dilakukan oleh pengelola perusahaan.

Corporate governance memiliki 5 prinsip aturan yang harus dijalankan demi terciptanya sebuah tata kelola perusahaan yang baik. Berdasarkan pada SK Menteri BUMN nomor Kep-117/MMBU/2002 pasal 3. Mengenai praktek 
penerapan corporate governance yaitu (1). Transparency, (2). Independency, (3). Accountability, (4). Responsibility, (5). Fairness. Penerapan prinsip-prinsip tersebut agar dapat berjalan dengan efektif dan efisien diperlukan pengawasan dan pengendalian yang baik dalam mengelola perusahaan dan hal ini dapat berjalan apabila independensi stakeholder perusahaan dapat dijaga dengan baik walaupun pengeloa tersebut merupakan anggota keluarga yang memiliki perusahaan maupun bukan pemilik sehingga proses tata kelola perusahaan berjalan secara baik.

Salah satu teori corporate governance menjelaskan bahwa perusahaan yang kepemilikannya dikuasai oleh keluarga cenderung memiliki dampak yang positif dan dapat mengurangi terjadinya konflik keagenan. Hal ini dikarenakan karena tujuan dari agen maupun prinsipan memiliki kesamaan karena terdapat beberapa prinsipan yang juga merupakan seorang agen. Namun dalam beberapa penelitian, Cucuellli dan Micuci (2008) menjelaskan bahwa kepemilikan saham keluarga memiliki dampak negatif terhadap kinerja keuangan. Hal ini disebabkan keluarga cenderung mengambil manfaat pribadi dan apabila terjadi permasalahan ada perusahaan juga keluarga cenderung memilih untuk menyelamatkan keuangan pribadi sendiri daripada untuk menyelamatkan kinerja keuangan. Penelitian lain juga pernah dilakukan oleh Anderson dan Reeb (2003) menjelaskan bahwa kepemilikan keluarga memiliki dampak negatif terhadap kinerja keuangan karena perlindungan hukum yang diberikan kepada investor dalam struktur kepemilikan cenderung lemah. Dalam hal ini, terdapat beberapa perbedaan hasil penelitian sehingga penelitian ini akan mengkaji tata kelola yang ada pada perusahaan keluarga.

\section{Mekanisme Corporate Governance}

Mekanisme corporate governance adalah sistem untuk mengendalikan dan mengarahkan kegiatan operasional perusahaan dan pihak yang ada pada perusahaan untuk mengurangi terjadinya masalah keagenan (Budiono, 2005). Purno dan Khafid (2013) juga menyatakan bahwa permasalahan keagenan dapat dikurangi dengan mekanisme corporate governance sehingga kinerja perusahaan dapat meningkat. Mekanisme corporate governance terbagi menjadi dua bagian yaitu internal dan eksternal. Mekanisme secara internal adalah pengendalian perusahaan menggunakan struktur dan proses internal pada perusahaan seperti Rapat Umum Pemegang Saham (RUPS), komposisi dewan direksi, komposisi dewan komisaris dan pertemuan direksi maupun pertemuan komisaris. Sedangkan mekanisme ekternal adalah pengendalian pasar dan mekanisme pasar.

Penelitian ini mengambil 3 variabel yang digunakan sebagai proksi mekanisme corporate governance yaitu (1). Komisaris Independen, (2). Ukuran Dewan Direksi, (3). Ukuran Komite Audit.

\section{a. Komisaris Independen.}

Komisaris

Independen merupakan bagian dari dewan komisaris perusahaan yang merupakan orgam perseroan yang memiliki tugas dalam mengawasi anggaran dasar secara umum maupun khusus dan memberikan masukan kepada direksi untuk kemajuan perusahaan. Dewan Komisaris dapat diangkat dan diberhentikan melalui Rapat Umum Pemegang Saham (RUPS). Salah satu bagian dalam dewan komisaris adalah komisaris independen (non-executive director) adalah pihak yang menjadi penengah dalam perselisihan antara manajer internal dan pihak yang mengawasi 
kebijakan manajemen (Fama dan Jense, 1983).

Komisaris independen memiliki kriteria yang telah ditetapkan menurut Surat Edaran BO No.9/12/DPNP. Adapun kriteria yang harus dimiliki adalah sebagai berikut:

1) Komisaris Independen tidak memiliki hubungan keuangan dengan perusahaan, seperti penghasilan, bantuan keuangan, pinjaman dari semua stakeholder perusahaan.

2) Komisaris Independen tidak memiliki hubungan kepengurusan terhadap perusahaan maupun seluruh pemangku kepentingan perusahaan.

3) Komisaris Independen tidak memiliki kepemilikan saham pada perusahaan.

Proporsi anggota komisaris Berdasarkan peraturan otoritas jasa keuangan nomor 57/POJK.04/2017 tentang penerapan tata kelola perusahaan efek yang melakukan kegiatan usaha sebagai penjamin emisi efek dan perantara dagang efek Pasal 19 bahwa komisaris independen minimal 30\% dari jumlah dewah komisaris yang ditentukan berdasar perhitungan sebagai berikut:

Komisaris Independen

$\overline{\text { Total Anggota Dewan Komisaris }}$ $100 \%$

\section{b. Ukuran Dewan Direksi}

Dewan Direksi adalah pihak yang bertanggungjawab penuh atas kepengurusan perusahaan efek untuk kepentingan perusahaan efek, sesuai dengan maksud dan tujuan Perusahaan Efek serta mewakili Perusahaan Efek, baik di dalam maupun di luar pengadilan sesuai dengan ketentuan anggaran dasar (Peraturan OJK Nomor 57/POJK.04/2017. Ukuran Dewan Direksi dihitung bedasarkan jumlah direksi yang ada pada perusahaan.

\section{c. Ukuran Komite Audit}

Komite audit adalah pihak yang bertanggungjawab dalam pengawasan laporan keuangan, mengawasi pelaksanaan audit eksternal maupun sistem pengendalian internal untuk mengurangi tindakan kecurangan yang dapat dilakukan oleh manajemen dengan mengawasi laporan keuangan. KNKG (2004) dalam mendukung tata kelola perusahaan yang baik, anggota komite audit dalam perusahaan diwajibkan memiliki 3 orang dalam kepengurusannya dan dalam tugasnya komite audit bertugas untuk membantu dewan komisaris dalam meningkatkan laporan keuangan, menciptakan iklim yang baik dan disiplin dalam pengelolaan perusahaan guna mengurangi terjadinya penyimpangan dan meningkatkan efektivitas audit internal maupun eksternal. Sekaredi (2011) menyatakan bahwa ukuran komite audit dapat diukur berdasar pada jumlah anggota komite audit pada perusahaan.

Penelitian terdahulu pada penelitian ini adalah penelitian yang dilakukan oleh Amyulianthy (2012) pengaruh struktur corporate governance terhadap kinerja perusahaan publik di Indonesia dengan menggunakan sampel perusahaan LQ45 dan menunjukan hasil bahwa kepemilikan institusional, kepemilikan manajerial, komisaris independen dewan direksi berpengaruh positif terhadap kinerja perusahaan.

Darmawati, dkk (2014) dalam penelitiannya juga menemukan pengaruh positif antara corporate governance dengan kinerja keuangan. Nuswandari (2009) pada penelitiannya pengaruh corporate governance perception index terhadap kinerja perusahan menemukan bahwa corporate governance berpengaruh positif signifikan terhadap kinerja keuangan 
perusahaan. Sam'ani (2008) melakukan penelitian tentang pengaruh good corporate governance dan leverage terhadap kinerja keuangan perbankan di BEI tahun 20042007. Hasil penelitian ini juga menunjukan bahwa kepemilikan institusional, aktivitas komisaris, ukuran dewan direksi, komisaris independen, komite audit, dan rasio leverage berpengaruh terhadap kinerja keuangan perusahaan.

\section{Hipotesis}

H1: Terdapat pengaruh Positif Komisaris Independen terhadap kinerja keuangan perusahaan keluarga di Indonesia.

H2: Terdapat pengaruh Positif Dewan Direksi terhadap kinerja keuangan perusahaan keluarga di Indonesia.

H3: Terdapat pengaruh Positif Komite Audit terhadap kinerja keuangan perusahaan keluarga di Indonesia.

\section{Kerangka Penelitian}

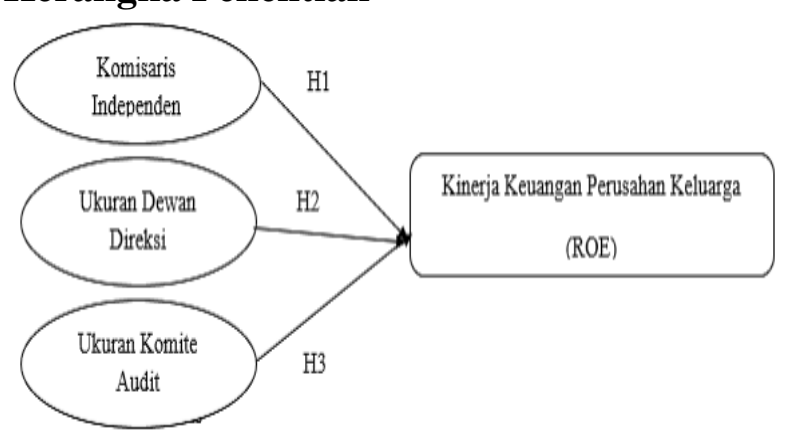

\section{METODE PENELITIAN}

\section{Populasi dan Sampel}

Populasi merupakan generalisasi atas objek yang memiliki kualitas dan karakteristik tertentu untuk dipelajari dan ditarik sebuah kesimpulan (Sugiyono, 2016). Populasi pada penelitan ini adalah perusahaan keluarga di Indonesia dengan sampel perusahaan keluarga yang terdaftar di Bursa Efek Indonesia tahun 2014-2018.

Populasi adalah wilayah generalisasi yang terdiri atas obyek atau subyek yang mempunyai kualitas dan karakteristik tertentu yang ditetapkan oleh peneliti untuk dipelajari dan kemudian ditarik kesimpulan (Sugiyono, 2016). Populasi yang digunakan dalam penelitian ini adalah perusahaan keluarga di Indonesia dengan sampel perusahaan keluarga yang terdaftar di Bursa Efek Indonesia tahun 2014-2018.

Teknik pengambilan sampel penelitian menggunakan teknik purposive sampling yaitu penentuan sampel dengan pertimbangan atau berdasarkan kriteria tertentu (Sugiyono, 2016). Adapun kriteria yang digunakan untuk memilih sampel adalah sebagai berikut:

1. Perusahaan Keluarga yang terdaftar di BEI pada periode 2014 sampai dengan 2018.

2. Terdapat komposisi komisaris independen, ukuran direksi dan ukuran komite audit.

3. Perusahaan yang menyediakan data secara lengkap sebagai kebutuhan analisis.

\section{Definisi Operasional}

1. Variabel Independen

Variabel independen yang digunakan dalam penelitian ini adalah Proporsi Dewan Komisaris yang dihitung berdasarkan jumlah dewan komisaris independen dibagi dengan jumlah seluruh dewan komisaris atau dengan rumus sebagai berikut:

$\frac{\text { Komisaris Independen }}{\text { Total Anggota Dewan Komisaris }} \times 100 \%$

Variabel independen yang kedua adalah Ukuran Dewan Direksi yang diukur berdasarkan jumlah Dewan Direksi yang ada pada perusahaan. Sedangkan Variabel ketiga penelitian ini adalah Ukuran Komite Audit yang ada pada perusahaan dengan melihat jumlag anggota komite audit yang ada pada perusahaan. 
2. Variabel Dependen

Variabel dependen yang digunakan dalam penelitian ini adalah Return on Equity (ROE). Penghitungan ROE adalah total pendapatan dibagi dengan laba bersih perusahaan.

\section{Teknik Analisis Data}

\section{Uji Asumsi Klasik}

\section{a. Uji Normalitas}

Uji Normalitas digunakan untuk menguji model regresi memiliki data yang berdistribusi normal atau tidak. Uji normalitas pada penelitian ini menggunakan uji kolmogorov smirnov.

b. Uji Multikoliearitas

Uji Multikolinearitas digunakan untuk menguji korelasi antara variabel bebas (independen). Pengamatan uji multikolinearitas pada penelitian ini menggunakan nilai tolerance dan variance inflation factor (VIF).

\section{c. Uji Autokorelasi}

Uji Autokrelasi digunakan untuk menguji model regresi dan korelasi antara kesalahan pengganggu pada periode $\mathrm{t}$ dengan periode $\mathrm{t}$ sebelumnya (Ghozali, 2006). Untuk mendetekdi adanya autokorelasi dalam penelitian ini menggunakan uji durbin watson.

\section{d. Uji Heteroskedastisitas}

Uji Heteroskedastisitas bertujuan menguji dalam model regresi terjadi ketidaksamaan varians dan residual satu pengamatan ke pengamatan yang lain. Jika variance dari residual satu ke pengamatan yang lain tetap, maka disebut heteroskedasitas. Model regresi yang baik adalah yang homoskedasitas atau yang tidak terjadi heterokedastisitas (Ghozali, 2006). Mendeteksi ada tidaknya heteroskedastisitas dapat dilakukan dengan uji Glejser yang menyatakan bahwa model regresi linier berganda tidak terdapat heteroskedastisitas.

\section{Uji Hipotesis}

\section{Uji Parsial (Uji T)}

Uji $\mathrm{t}$ digunakan untuk menguji signifikan secara parsial pengaruh variabel independen terhadap variabel dependen dalam model regresi yang sudah dihasilkan. Dalam penelitian ini digunakan tingkat signifikan 5\% $(\alpha=$ $0,05)$. Kriteria pengujian uji $t$ adalah sebagai berikut: $\mathrm{HO}$ diterima jika Sig $\mathrm{t}$ hitung $>\alpha$ (tingkat signifikan yang digunakan). Ha diterima jika Sig t hitung $<\alpha$ (tingkat signifikan yang digunakan).

Dengan langkah-langkah yang dilakukan dalam pengujian hipotesis adalah menggunakan analisis Regresi berganda dengan rumus sebagai berikut: $\mathrm{ROE}_{\mathrm{it}}=\mathrm{a}+\beta_{1} \mathrm{KI}_{\mathrm{it}}+\beta_{2} \mathrm{UKA}_{\mathrm{it}}+\beta_{3}$ $\mathrm{UDD}_{\mathrm{it}}+\mathrm{e}$

Dimana:

$\mathrm{KI}_{\mathrm{it}}=$ Komisaris Independen

UDA $_{\text {it }}=$ Ukuran Komite Audit

UDD $_{\text {it }} \quad=$ Ukuran Dewan Direksi

\section{Hasil Penelitian}

\section{Hasil Uji Asumsi Klasik}

a. Normalitas

Uji normalitas data menggunakan uji KolmogorovSmirnov dengan hasil sebagai berikut:

Tabel 1. Uji Normalitas Distribusi Data ROE

\begin{tabular}{|c|c|c|c|}
\hline Variabel & Kolmogorov-Smininov & Asymp.sig & Keterangan \\
\hline Unstandardized Residual & 1,058 & 0,213 & Normal \\
\hline
\end{tabular}

Sumber: Data diolah, 2019. 
Hasil uji normalitas ROE mendapatkan nilai sebesar 0,213 > 0,050 sehingga dapat dinyatakan variabel dependen Return on Equity (ROE) berdistribusi normal.

\section{b. Multikolinearitas}

Uji multikolinearitas pada penelitian ini dapat dilihat pada tabel di bawah ini.

Tabel 2. Uji Multikolinearitas Dengan Melihat Variance Inflation Factor (VIF)

\begin{tabular}{|c|c|c|c|}
\hline \multirow{2}{*}{ Variabel } & \multicolumn{2}{|c|}{ Collinearity Statistik } & \multirow{2}{*}{ Keterangan } \\
\cline { 2 - 3 } & Tollerance & VIF & \\
\hline KI & 0,966 & 1,035 & Tidak terjadi mulitikolinearitas \\
\hline UDD & 0,966 & 1,035 & Tidak terjadi mulitikolinearitas \\
\hline UKA & 0,976 & 1,025 & Tidak terjadi mulitikolinearitas \\
\hline
\end{tabular}

Sumber: Data diolah, 2019.

Berdasar pada hasil uji multikoliearitas di atas, dapat diketahui nilai variance inflation factor (VIF) semua variabel independen kurang dari 10 dan nilai tolerance masing-masing variabel diatas 10\%, sehingga uji multikolineritas terpenuhi baik dengan variabel dependen ROE.

\section{c. Autokorelasi}

Pengujian adanya fenomena autokorelasi dalam data yang dianalisis dapat dilakukan dengan menggunakan Durbin Watson Test dengan hasil sebagai berikut:

Tabel 3. Hasil Uji Durbin Watson

\section{ROE}

\begin{tabular}{|c|c|c|c|}
\hline Variabel & Durbin Watson & $\begin{array}{c}\mathrm{dL} \\
\left(\mathrm{k}^{\prime}=4\right)\end{array}$ & $\begin{array}{c}\mathrm{dU} \\
\left(\mathrm{k}^{\prime}=4\right)\end{array}$ \\
\hline ROE & 1,762 & 1,754 & 1,822 \\
\hline
\end{tabular}

Sumber: Data diolah, 2019.

Hasil perhitungan Durbinwatson dibandingkan dengan nilai $\mathrm{d}$ tabel pada $\alpha=0.05$. Tabel $d$ memiliki dua nilai, yaitu nilai batas atas (dU) dan nilai batas bawah (dL) untuk berbagai nilai $\mathrm{n}$ dan $\mathrm{k}$. sehingga dapat disimpulkan tidak terjadi autokorelasi pada variabel dependen ROE.

\section{d. Heteroskedastisitas}

Uji heteroskedastisitas digunakan untuk mengetahui ada atau tidaknya penyimpangan asumsi klasik heterokedastisitas, yaitu adanya ketidaksamaan varian dari residual untuk semua pengamatan pada model regresi. Dengan hasil sebagai berikut sebagai berikut:

Tabel 4. Hasil Uji

Heteroskedastisitas ROE

\begin{tabular}{|c|c|}
\hline Variabel & Signifikansi \\
\hline KI & 1,000 \\
\hline UDD & 1,000 \\
\hline UKA & 1,000 \\
\hline
\end{tabular}

Sumber: Data diolah, 2019.

Berdasarkan hasil output uji glejser diatas tidak ada satupun variabel yang signifikan sehingga dapat dinyatakan model regresi tidak mengandung heteroskedastisitas.

\section{Hasil Uji Regresi Linier Berganda}

Tabel 5. Hasil Uji Analisis Regresi Linear Berganda

\begin{tabular}{|c|c|c|c|}
\hline Variabel & Nilai Beta $(\beta)$ & t-hitung & P-Value \\
\hline Konstanta & $-0,018$ & $-0,701$ & 0,484 \\
\hline KI & 0,097 & 2,530 & 0,012 \\
\hline UKA & 0,056 & 1,561 & 0,120 \\
\hline UDD & 0,104 & 4,103 & 0,000 \\
\hline
\end{tabular}

Sumber: Data SPSS (Diolah)

Tabel 5 menunjukan bahwa, Proporsi Komisaris Independen memberikan pengaruh positif signifikan terhadap Return on Equity (ROE) perusahaan keluarga di Indonesia. Hal ini ditunjukan oleh nilai probabilitas proporsi komisaris independen mendapatkan nilai sebesar 0,012 lebih kecil dari nilai alpha 5\%. Ukuran Komite Audit dalam tabel 5 menunjukan bahwa ukuran komite audit tidak berpengaruh positif signifikan terhadap ROE perusahaan keluarga di Indonesia, hal ini dapat dilihat dari nilai probabilitas ukuran komite audit mendapatkan nilai sebesar 0,120 lebih besar dari nilai alpha 
5\%. Sedangkan Ukuran Dewan Direksi memiliki pengaruh positif signifikan terhadap ROE perusahan keluarga di Indonesia, hal ini dapat dilihat dari nilai probabilitas ukuran dewan direksi mendapatkan nilai sebesar 0,000 lebih kecil dari nilai alpha 5\%.

\section{Pembahasan}

a. Uji Hipotesis Komisaris Independen terhadap Kinerja Keuangan (ROE)

Hasil uji hipotesis menunjukan bahwa proporsi komisaris independen memberikan pengaruh signifikan terhadap Return on Equity (ROE) perusahaan keluarga di Indonesia. Hal ini ditunjukan oleh nilai probabilitas proporsi komisaris independen mendapatkan nilai sebesar 0,012 lebih kecil dari nilai alpha 5\%. Hasil analisis ini sejalan dengan penelitian Sam'ani (2008) tentang pengaruh good corporate governance dan leverage terhadap kinerja keuangan pada perbankan yang terdaftar di Bursa Efek Indonesia (BEI) Tahun 2004-2007.

\section{b. Uji Hipotesis Ukuran Komite Audit terhadap Kinerja Keuangan (ROE) \\ Ukuran komite audit dalam} penelitian ini menunjukan bahwa ukuran komite audit tidak berpengaruh signifikan terhadap ROE perusahaan keluarga di Indonesia, hal ini dapat dilihat dari nilai probabilitas ukuran komite audit mendapatkan nilai sebesar 0,120 lebih besar dari nilai alpha 5\%. hasil ini sejalan dengan penelitian Riniati (2015), Lestari (2011), Widyaningrum (2014), dan Kartikasari (2016). komite audit berpengaruh secara positif namun tidak signifikan, hal ini pengaruh positif yang diberikan oleh model ini karena komite audit adalah pihak yang membantu dewan komisaris dalam melakukan proses monitoring laporan keuangan untuk meningkatkan kredibilitas laporan keuangan.

c. Uji Hipotesis Ukuran Dewan Direksi terhadap Kinerja Keuangan (ROE)
Hasil Uji Ukuran Dewan Direksi memiliki pengaruh signifikan terhadap ROE perusahan keluarga di Indonesia, hal ini dapat dilihat dari nilai probabilitas ukuran dewan direksi mendapatkan nilai sebesar 0,000 lebih kecil dari nilai alpha 5\%. Hasil analisis ini sejalan dengan penelitian Sam'ani (2008) dengan penelitian pengaruh good corporate governance dan leverage terhadap kinerja keuangan pada perbankan yang terdaftar di BEI tahun 2004-2007. yang menyatakan bahwa kepemilikan institusional, aktifitas komisaris, ukuran direksi, komisaris independen, komite audit dan leverage berpengaruh terhadap kinerja keuangan perbankan.

\section{KESIMPULAN DAN SARAN}

\section{Kesimpulan}

Penelitian ini dilakukan untuk menganalisis pengaruh mekanisme corporate governance yang diproksikan dengan proporsi komisaris independen, ukuran komite audit, dan ukuran dewan direksi. Berdasarkan hasil analisis data, proporsi komisaris independen dan ukuran dewan direksi berpengaruh posisitf secara signifikan namun untuk variable ukuran komite audit berpengaruh positif namun tidak signifikan hal tersebut memiliki pengaruh positif namun tidak signifikan karena komite audit merupakan pihak yang membantu dewan komisaris dalam meningkatkan kredibilitas laporan keuangan.

\section{Saran}

1. Penelitian ini menggunakan sampel perusahaan keluarga dengan mengambil sampel selama lima tahun sehingga dapat ditambah tahun pengamatan untuk hasil yang lebih optimal.

2. Indikator pada penelitian ini dapat ditambah dengan indikator lainnya dalam pelaksanaan GCG dengan 
memasukkan variabel-variabel lainnya seperti kepemilikan manajerial, kepemilikan institusi, aktivitas dari dewan direksi maupun dewan komisaris sehingga dapat lebih memprediksi pengaruh faktorfaktor lain terhadap kinerja keuangan pada perusahaan keluarga.

3. Ukuran kinerja perusahan pada penelitian ini hanya menggunakan rasio profitabilitas yaitu menggunakan ROE sehingga penelitian lain dapat menggunakan ukuran lain untuk melihat kinerja perusahaan.

\section{DAFTAR PUSTAKA}

Allouche, et. all, (2008). The Impact of Family Control on the Performance and Financial Characteristics of Family versus Nonfamily Business in Japan: A Matched-Pair Investigation. Family Business Review XXI.

Amyulianthy, Rafriny. 2012. Pengaruh Struktur Corporate Governance terhadap Kinerja Perusahaan Publik Indonesia. Jurnal Liquidity, Volume 1. No. 2, Juli-Desember 2012. Fakultas Ekonomi Universitas Pancasila.

Anderson, R. C., \& Reeb, D. M. (2003). Founding-family ownership and firm performance: evidence from the $S \& P$ 500. Journal of Finance 58 (3), 13011328.

Bank Indonesia. Peraturan Bank Indonesia. Nomor 8/4/PBI/2006 tentang Pelaksanaan Good Corporate Governance.

Boediono, Gideon Sb. 2005. Kualitas Laba: Studi Pengaruh Mekanisme
Corporate Governance dan Dampak Manajemen Laba Dengan Menggunakan Analisis Jalur. Simposium Nasional Akuntansi VIII Solo 15 - 16 September 2005.

Block,J., R. Jaskiewicz, and D.Miller."Ownership versus management effects on performance in family and founder companies: A Bayesian reconciliation", Journal of Family Business Strategy, 2011.

Charbel, S., Elie, B., \& Georges, S. (2013). Impact of family involvement in ownership management and direction on financial performance of the Lebanese firms. International Strategic Review 1, 30-41.

Chen, H. W. (2013). Family Ties, Board Compensation and Firm Performance. Journal of Multinational Financial Management 23, 255-271.

Claessens, Stijn, Simeon Djankov,and Larry H.P. Lang, "The Separation of Ownership and Control in East Asian Corporations", Chinese University of Hong Kong, 1999.

Cucculelli, M., and G. Micucci (2008). "Family succession and firm performance: Evidence from Italian firms," Journal of Corporate Finance14, 17-31.

Fama, E. F., \& Jensen, M. C. (1983). Separation of Ownership and Control. Journal of Law \& Economics 26 (2, 301-325.

Faisal. 2005. Analisis Agency Cost, Struktur Kepemilikan dan Mekanisme Corporate Governance. Jurnal Riset Akuntansi Indonesia, Volume 8, No.2, Hal. 175-190 
Ghozali, Imam. 2006 Aplikasi Analisis multivariate dengan Program SPSS . Badan penerbit Universitas Diponegoro, Semarang.

Herawaty, V. 2008. Peran Praktek Corporate Governance Sebagai Moderating Variable dari Pengaruh Earnings Management terhadap Nilai Perusahaan. Jurnal Akuntansi dan Keuangan 10(2): 97-108.

Jaggi, B., Leung, S., \& Gul, F. (2009). Family control, board independence and earnings management: Evidence based on Hong Kong firms. Journal Accounting Public 28, 281-300.

Jensen, M. C. and Meckling, W. H. 1976. Theory of The Firm: Managerial Behavior, Agency Cost and Ownership Structure. Journal of Financial Economics.

Kartikasari, Y.D., 2016. Pengaruh Good Corporate Governance dan Modal Intelektual Terhadap Kinerja Keuangan pada Perusahaan Sektor Keuangan yang terdaftar di Bursa Efek Indonesia tahun 2011-2015. Eprints UNY. Yogyakarta.

Leung, S., Richardson, G., \& Jaggi, B. (2014). Corporate board and board committee independence, firm performance, and family ownership concentration: An analysis based on Hong Kong firms. Journal of Contemporary Accounting \& Economics 10, 16-31.

Lestari, Eko Dyah, 2011. Pengaruh Good Corporate Governance terhadap Kinerja Keuangan (Studi Kasus pada Perusahaan Perbankan yang Terdaftar di Bursa Efek Indonesia tahun 2007-2009. Eprints UNDIP. Semarang.
Lukviarman, N. 2016. Corporate Governance "Menuju Penguatan Konseptual dan Implementasi di Indonesia, PT Era Adicitra Intermedia, Solo.

Miralles-Marcelo, J. L.\& Miralles-Quiró s, M.M.(2006). The role of an illiquidity risk factor in asset pricing: Empirical evidence from the Spanish stock market.Quarterly Review of Economics and Finance, 46 (2), 254267.

Nuryaman. 2008. Pengaruh konsentrasi kepemilikan, Ukuran Perusahaan, dan Mekanisme GCG Terhadap Manajemen Laba. Simposium Nasional Akuntansi XI Pontianak.

Nuswandari, C. 2009. Pengaruh Corporate Governance Index terhadap Kinerja Perusahaan pada Perusahaan yang terdaftar di Bursa Efek Jakarta. Jurnal Ekonomi dan Bisnis. September 2009, hal. 70-84.

Purno, B Listyo. dan Khafid, Muhamad. 2013. Pengaruh Mekanisme Good Corporate Governance terhadap Kinerja Perbankan. Symposium Nasional Akuntansi XVI, 25-28 September 2013. Manado

Riniati, K., 2015. Pengaruh Komisaris Independen dan Komite Audit Terhadap Kinerja Perusahaan (Perusahaan yang Terdaftar di BEI 2011-2013), Eprints UNY. Yogyakarta

Sama'ni. 2008. Pengaruh Good Corporate Governance dan Leverage terhadap Kinerja Keuangan pada Perbankan yang Terdaftar di Bursa Efek Indonesia (BEI) tahun 2004 - 2007. Thesis. Semarang: Fakultas Ekonomi Universitas Diponegoro 
Santoso, A.R.C., "Pengaruh Corportate Governance dan Strategi Perusahaan Terhadap Kinerja Keuangan Perusahaan Keluarga di Indonesia, Proceedings NCAB-2017, Yogyakarta

Sekaredi, Sawitri. 2011. Pengaruh Corporate Governance terhadap Kinerja Keuangan Perusahaan. Fakultas Ekonomi Universitas Diponegoro Semarang, Akses 2, April 2015

Sugiyono, (2006), Metode Penelitian Bisnis, Cetakan keenam, Penerbit Alfabeta, Bandung

Ujiantho, Arif Muh. dan B.A. Pramuka. 2007. "Mekanisme Corporate Governance, Manajemen Laba dan Kinerja Keuangan.'Simposium Nasional Akuntansi X, IAI, Makasar 2007.

Widyaningrum, A, 2014, Pengaruh Audit Internal, Intellectual Capital. Dan Good Corporate Governance terhadap Kinerja Keuangan Perusahaan (Perusahaan Perbankan yang terdaftar di BEI Periode 20112013). Eprints UNY. Yogyakarta. 